\title{
SYNTHESIS OF FATTY DIETHANOLAMIDE FROM Calophyllum inophyllum L. KERNEL OIL VIA ENZYMATIC REACTION
}

\author{
D. Suhendra ${ }^{1}$, E. R. Gunawan ${ }^{1} *$ and L. Kusumawati ${ }^{1}$ \\ ${ }^{1}$ Department of Chemistry, Faculty of Mathematics and Science, University of Mataram \\ Jl. Majapahit No. 62 Mataram, 83125, West Nusa Tenggara-Indonesia \\ *E-mail : erinryantin@unram.ac.id
}

\begin{abstract}
In the present paper, fatty diethanolamide has been produced from Calophyllum inophyllum L (local name: nyamplung) kernel oil. The synthesis of fatty diethanolamide was performed by reacting triglycerides from the nyamplung kernel oil with diethanolamine catalysed by Thermomyces lanuginosus immobilized lipase (Lipozyme TL IM). The optimum reaction conditions were of the ratio of oil to diethanolamine at 1:5 (g:mmol), amount of enzyme at $0.05 \mathrm{~g}$, reaction temperature at $40^{\circ} \mathrm{C}$, and incubation time at $2 \mathrm{~h}$. The percentage yield of fatty diethanolamide at optimum condition was $44 \%$. Characterization of the products were performed using gas chromatography-mass spectrometry and Fourier transform infrared spectroscopy

Keywords: Fatty Diethanolamide, Enzymatic Reaction, Lipozyme, Calophyllum inophyllum L.
\end{abstract}

○ RASĀYAN. All rights reserved

\section{INTRODUCTION}

Fatty diethanolamide is widely used as a surfactant in pharmaceutical and cosmetic products. ${ }^{1-3}$ Surfactant can be used as wetting, emulsion, a solubilizing and foaming agent. Currently, production of fatty diethanolamide mainly uses vegetable oils as raw materials, such as castor oil, pongamia oil and jatropha oil and coconut oil ${ }^{4-6}$ or from pure fatty acids which are quite expensive when used as raw materials ${ }^{7}$.

In this research, nyamplung kernel oil has been used as a source of triglycerides to produce fatty diethanolamide. Nyamplung kernel oil is one of vegetable oil that has the potential to be developed as a raw material for fatty diethanolamide synthesis. Nyamplung plants are widely distributed and these plants are not seasonal plants, thus they can be fruitful throughout the season ${ }^{8}$. The water and oil content of nyamplung kernel is $3-4 \%$ and $55-70 \%$, respectively. The largest fatty acid composition of nyamplungkernel oil is oleic acid (46-48\%), linoleic (21-25\%), palmitic (15-16\%) and stearic acid (12$13 \%)^{9,10}$.

Industrially, fatty diethanolamide can be produced using chemical catalysts with oil substrate and alkanolamine. However, this synthesis is only possible at high temperatures and high pressures ${ }^{11-13}$. Therefore, an enzymatic process has been developed to synthesize fatty diethanolamide from vegetable oils using lipase as biocatalysis. Lipase is able to catalyze a reaction in a short time, at low temperature and low pressure. ${ }^{14,15}$

In this study, the optimization reactions have been performed to synthesize fatty dietanolamide from nyamplung kernel oil with the following variables: time reaction, temperature, ratio substrate and amount of enzyme. The enzyme used as a catalyst is the immobilized enzyme from Thermomyces lanuginosus or Lipozyme TLIM.

\section{Material and Methods}

\section{EXPERIMENTAL}

All reagents were purchased from commercial suppliers and the reagents were of analytical grade: hexane, chloroform, diethyl ether and sodium sulphate anhydrate were purchased from Tokyo Chemical Industry (TCI, Japan), Thermomyces lanuginosus immobilized lipase (Lipozyme TL IM) was from Novo Rasayan J. Chem., 12(2), 765-772(2019)

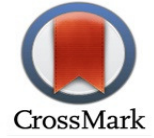


Nordisk (Denmark), and diethanolamine was from Merck (Germany). The oil was extracted from the nyamplung seed.

\section{General Procedure for Extraction of Nyamplung Oil}

The procedure for the extraction of nyamplung oil was used procedures as described in our previous publication ${ }^{16}$. Nyamplung oil is extracted from nyamplung seeds using the Soxhlet extraction method and the solvent used is hexane. The Soxhlet extraction process takes place during $6 \mathrm{~h}$. The oil produced separated from hexane using a rotary evaporator at $45^{\circ} \mathrm{C}$ with a rotation rate of $120 \mathrm{rpm}$. The water content in the oil is removed by adding sodium sulphate anhydrous. Purification of the oil was performed using silica gel which was placed in column chromatography. The eluent used in this process is a mixture of diethyl ether and hexane $(13: 87 \mathrm{v} / \mathrm{v})$.

\section{General Procedure for Synthesis of Fatty Diethanolamide}

Generally, the synthesis of fatty diethanolamide from nyamplung oil was using the modified procedure of Gunawan et al (2018) ${ }^{16}$. The $20 \mathrm{~mL}$ of nyamplung kernel oil dissolved in hexane was reacted with diethanolamine in the presence of an amount of Lipozyme TL IM. The reaction takes place in the water shaker bath at the shaking rate of $125 \mathrm{rpm}$ and certain reaction time and temperature. The product in the hexane phase was purified and determined by gravimetric method. To obtain the maximum product, it is necessary to determine the optimum reaction conditions. Several variables observed were incubation period, the concentration of enzyme, the ratio of substrates, and temperature. The study of the effect of the reaction period has been carried out by varying the length of the reaction at $1,2,3,4$, and 5 hours, while other variables were fixed. This study was performed by reacting 2 grams of nyamplung oil, 15 mmol diethanolamine, and 0.1 gram Lipozyme TLIM in $20 \mathrm{~mL}$ of hexane. The mixture was reacted in a water shaker bath at $40^{\circ} \mathrm{C}$. Then, the fatty diethanolamide in the hexane phase was purified and determined by gravimetric method. The study of the effect of temperature was observed at the temperature of $30,40,50,60$ and $70^{\circ} \mathrm{C}$, while other parameters were fixed and performed as described earlier, except length of reaction that used the optimum reaction time. Meanwhile, the study of the effect of concentration of enzyme was carried out by varying the amount of enzyme of $0.05,0.1,0.15,0.20$ and $0.25 \mathrm{~g}$, while other variables such as the length of reaction and the temperature of reaction use optimum conditions that have been determined previously. Another study is the effect of substrates ratio. This study was conducted by varying the ratio of nyamplung oil to the concentration of dietanolamine $(2 \mathrm{~g}$ nyamplung oil : mmol of dietanolamine). The variations of diethanolamine concentrations used were 5 , $10,15,20$ and $25 \mathrm{mmol}$.

\section{Characterization}

The characterization of the product was done by several methods. Determination of fatty diethanolamide content in the product was carried out by using the gravimetric method. Qualitative analysis was carried out using Thin Layer Chromatography (TLC) and Fourier Transform Infra-Red Spectroscopy (FTIR). The spectrophotometer FTIR used was FTIR Spectrophotometer Perkin Elmer Frontier (USA) model. Meanwhile, the determination of fatty diethanolamide composition was carried out using Gas Chromatography-Mass Spectrometry (GC-MS). The GC-MS (Shimadzu Model GCMS-QP2010 Ultra) equipped withRtx ${ }^{\mathrm{TM}}-5$ capillary columns length $30 \mathrm{~m}$ and inner diameter $0.25 \mathrm{~mm}$ from Restek USA.

\section{Effect of Incubation Time}

\section{RESULTS AND DISCUSSION}

In this research, the optimization of reaction length was performed by varying the length of reaction from 1 to $5 \mathrm{~h}$. Figure-1 depicts the effects of incubation time. The number of product increases with the increase of incubation time and the optimum conditions are achieved at $2 \mathrm{~h}$. This result is more effective compared with the other work ${ }^{1}$ that use triglyceride as a substrate. Triglycerides need longer time to be cut off to free fatty acids that can react with diethanolamine. The optimum reaction time of the fatty amide synthesis without the presence of a catalyst is about $10 \mathrm{~h}$, which is way longer compared to that of 
with the presence of a catalyst, furthermore, the reaction also requires high temperature to complete $\left(140^{\circ} \mathrm{C}\right)^{17}$.

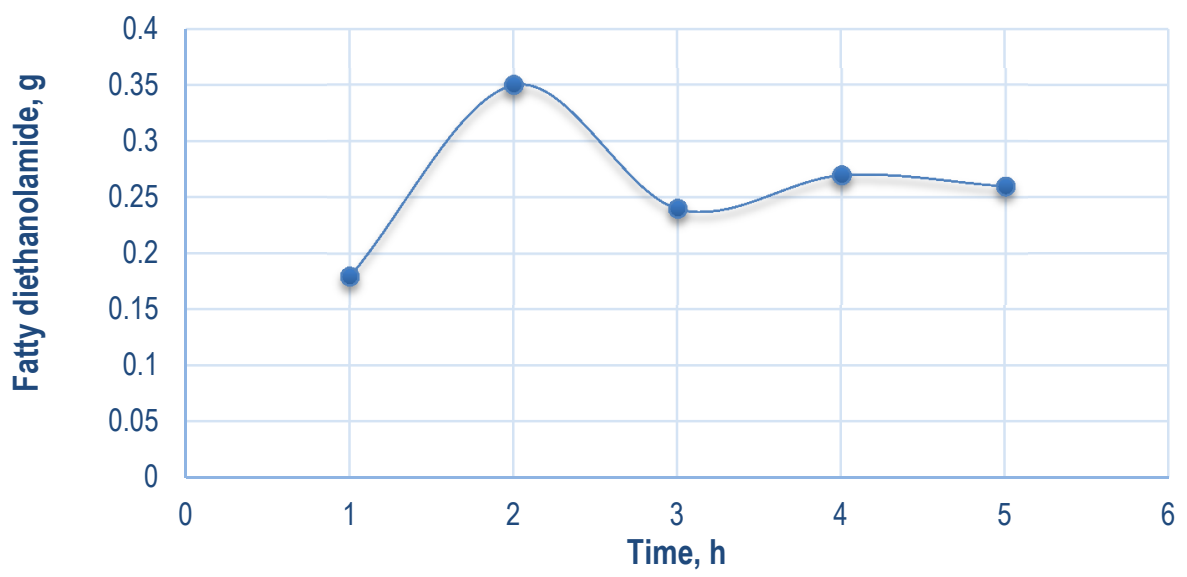

Fig.-1: Effect of Incubation Time

After $3 \mathrm{~h}$ of the incubation time, the product was decreased. This may due to some mass-transfer limitations, which inevitably arise in a reaction mixture containing a high proportion of solid product, or the reaction reaches the equilibrium state where the rate of forward reaction was equal to the backward reaction. After exceeding the optimum reaction time, the enzyme will be denatured slowly. Consequently, the enzyme activity will decrease ${ }^{18}$. The duration of the reaction may affect substrate conversion, stability, and enzyme activity ${ }^{19,20}$.

\section{Effect of Temperature}

In addition to the incubation time, the reaction temperature also affects the amount of fatty dietanolamide produced. In the enzymatic reaction, the temperature has a large effect on the activity or stability of the enzyme, reaction rate and solubility of the substrate ${ }^{21}$.

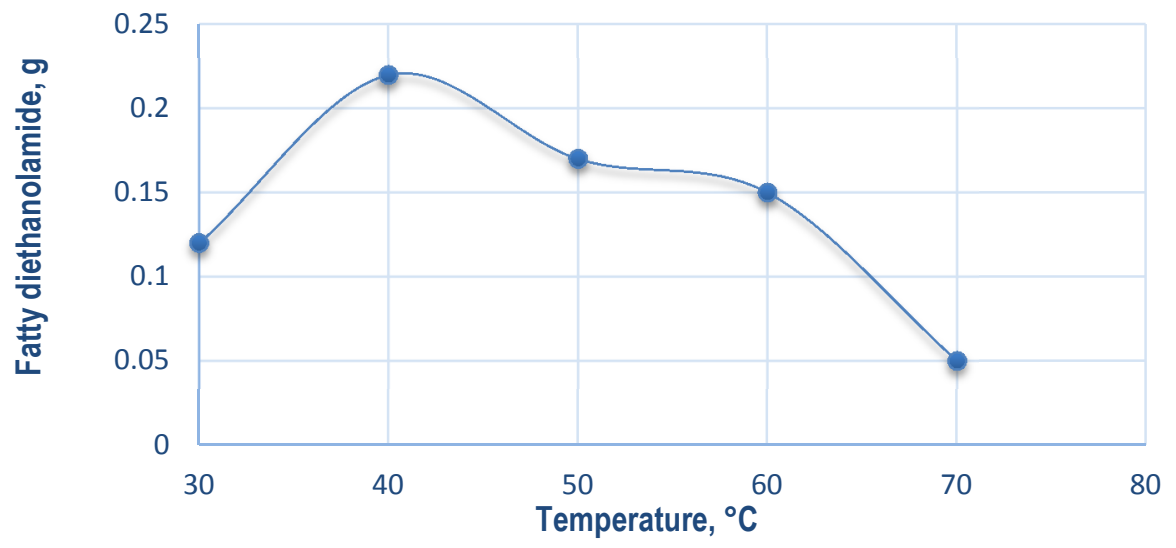

Fig.-2: Effect of Temperature

As shown in Fig.-2, up to a temperature of $40^{\circ} \mathrm{C}$, the number of products increases with increasing temperature, and at a temperature of $40-50^{\circ} \mathrm{C}$ the number of products decreases, significantly. The reason is that at higher temperatures the reaction will be faster because the solubility of the substrate increases and the collision between particles is rapid. As well as Kim et $\mathrm{al}^{21}$ that lipase activity is very good at 30$40^{\circ} \mathrm{C}$. Fig.-2also shown that above $50^{\circ} \mathrm{C}$, the amount of the product drops dramatically. This may be caused by unfolded structures of the enzyme that affect the active site of the enzyme ${ }^{20}$.

\section{Effect of Enzyme Concentration}

Enzymes are proteins that catalyze biochemical reactions. Enzymes may increase the rate of a reaction without altering the equilibrium position, for both forward and reverse reactions, in which the reaction 
rate increases with the same multiple ${ }^{22}$. A large amount of substrate is needed to produce a large number of products. Nevertheless, the amount of enzyme used should be as minimal. Economically, a high amount of lipase enzymes will require a high $\cos ^{23}$. Therefore, it is necessary to optimize the number of enzymes to determine the minimum amount of enzymes that can produce maximum products. Any change in the amount of products in a given period of time will depend on the increase of the enzyme amount.

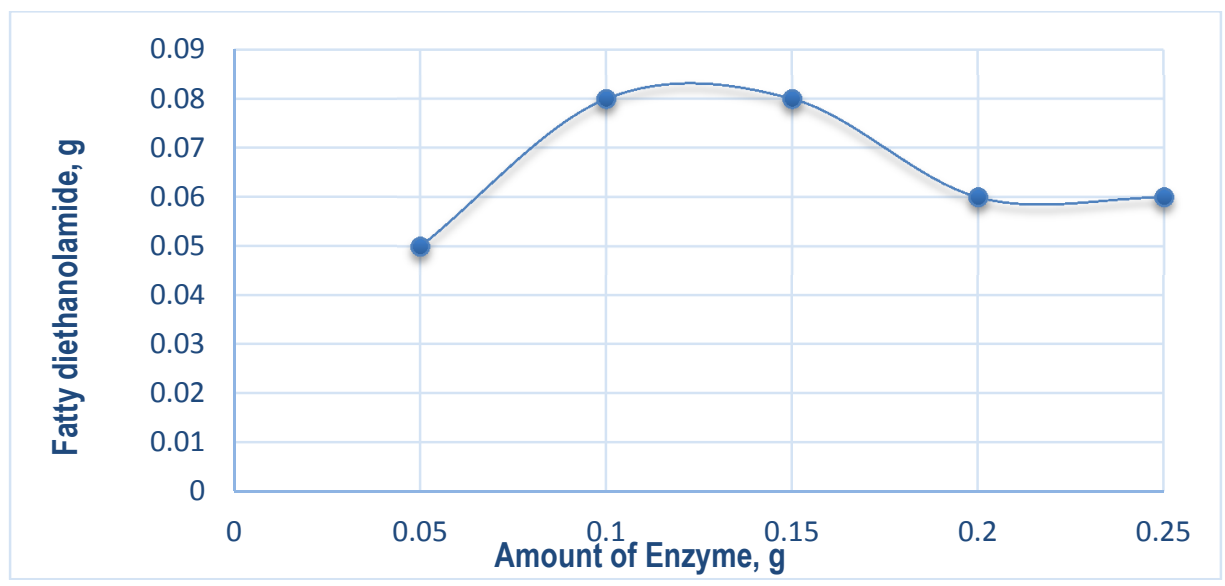

Fig.-3: Effect of Enzyme Concentration

As shown in Fig.-3, the optimum enzyme amount to produce the highest amount of the product is 0.1 to $0.15 \mathrm{~g}$. A researcher ${ }^{24}$ has reported that enzyme concentrations generally have a greater effect in reducing hydrolysis time compared to temperature increases. Enzyme activity will increase along with the increase of enzyme concentration to the substrate. In addition, the concentration of enzymes on a fixed substrate will lead to a higher reaction rate. When the enzyme concentration is higher than $7.5 \%$, there will be no increase in the amount of the product because it is estimated that the active side of the enzyme is saturated. Ideally, there should be no decrease in the amount of product yielded after the maximum point. However, there is a slight decrease in the product by increasing the amount of enzymes, this may due to the losses of some products at the purification process.

\section{Effect of Substrate Ratio}

This study was carried out by varying the concentration of diethanolamine from 5 to $25 \mathrm{mmol}$, at $5 \mathrm{mmol}$ intervals.

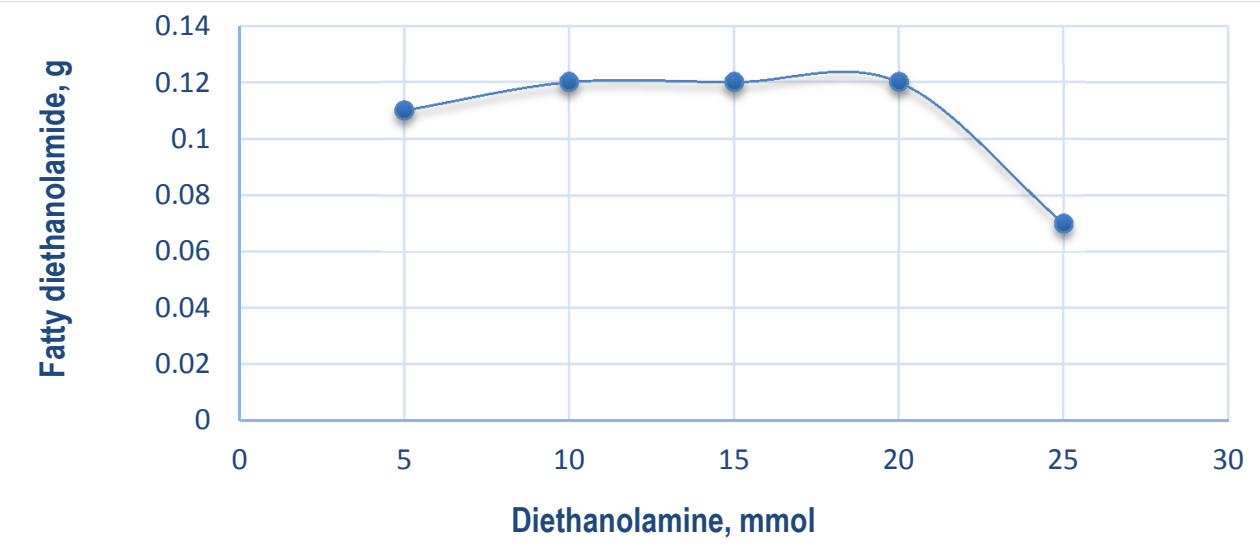

Fig.-4: Effect of Substrate Ratio

Figure-4 depicts that the amount of fatty diethanolamide goes up as the substrate amount increases. However, the product decreases when the amount of diethanolamine used was $25 \mathrm{mmol}$. According to Worthington $^{25}$, enzyme activity can be inhibited by excessive amounts of substrate. This is because of the 
higher the number of substrates, the more competing substrate molecules to attach to the active side of the enzyme. As a result, the active side of the enzyme will be blocked and can prevent other substrates from reacting, consequently the reaction rate decreases and reduces the number of products produced.This is also supported by the research of Kim et $\mathrm{al}^{21}$ revealed that substrate concentration that is too high increases viscosity, makes the interaction between reactants become ineffective and inhibits the reaction because the substrate can act as a barrier. As shown in Fig.-4, the maximum yield obtained was at the amount of diethanolamine $10 \mathrm{mmol}$ or ratio of oil and diethanolamine is $1: 5(\mathrm{~g}: \mathrm{mmol})$. Lee et $\mathrm{al}^{26}$ report in their study on the synthesis of palm oil-based diethanolamide, that the amount of diethanolamine used was $3 \mathrm{mmol}$ or the ratio oil and diethanolamine of 1:3.

\section{Enlarge the Reaction}

Enlargement of the reaction of 5 times has been carried out using the optimum reaction conditions (Table1) obtained from previous optimization stages. Fatty diethanolamide was synthesized by reacting diethanolamine with triglycerides (nyamplung kernel oil) in the presence of lipase (lipozyme TL IM) as a biocatalyst.

Table-1: The Optimum Conditions of Fatty Diethanolamide Synthesis

\begin{tabular}{c|c}
\hline Parameters & Condition \\
\hline Incubation Time & $2 \mathrm{~h}$ \\
\hline Temperature & $40^{\circ} \mathrm{C}$ \\
\hline Rasio Diethanolamine $(\mathrm{mmol}):$ Nyamplung oil $(\mathrm{g})$ & 5 \\
\hline Rasio Nyamplung Oil $(\mathrm{g}):$ Lipase $(\mathrm{g})$ & 20 \\
\hline
\end{tabular}

As shown in Scheme-1, in the synthesis reaction of fatty diethanolamide there is glycerol, which is a byproduct of the reaction. Purification of the fatty diethanolamide was done to obtain a pure product witha higher quantity. The conversion percentages of synthesis of fatty diethanolamide from nyamplung kernel oil are about $44 \%$.However, this result is lower than that of Lokhande ${ }^{13}$. They successfully synthesized fatty diethanolamide from mango seed oil (69\%) using a chemical catalyst, and the reaction took place at high temperatures $\left(100^{\circ} \mathrm{C}\right)$ as well as a long time $(10 \mathrm{~h})$.
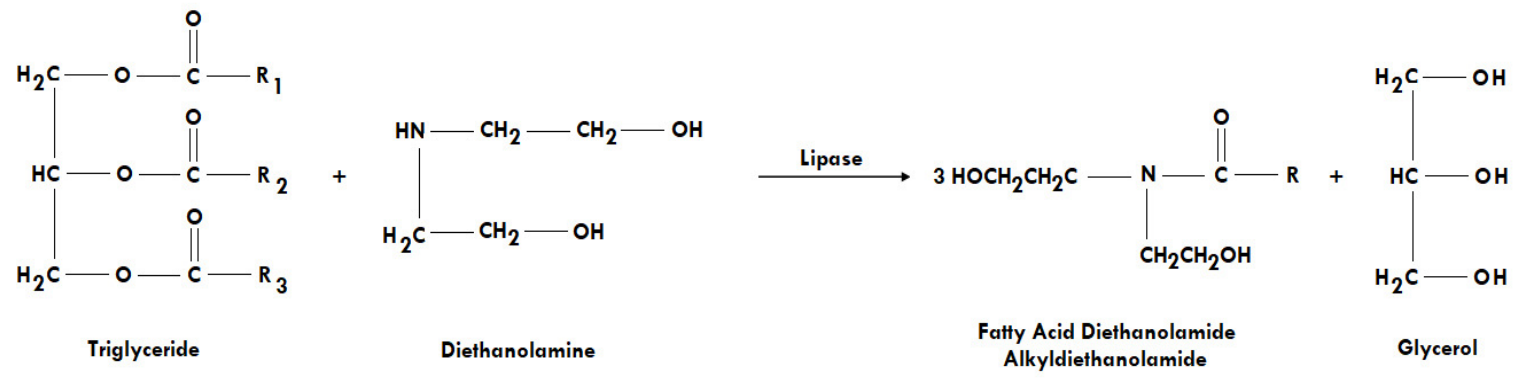

Scheme-1: Reaction of Fatty Diethanolamide Synthesis

\section{Characterization of Fatty Diethanolamide}

The preliminary qualitative test was performed by TLC.The purified fatty diethanolamide were dissolved into hexane.The eluent used was diethyl ether-hexane system $(13: 87 \mathrm{v} / \mathrm{v})$. The result showed that the $R_{\mathrm{f}}$ value of the fatty diethanolamide was 0.89 , while the $R_{f}$ value of the standard was 0.87 . The similarity of this $R_{f}$ value indicates that the product can be identified as fatty diethanolamide. The next qualitative test was carried out by using FTIR. The spectrum of FTIR of the product is similar to that spectrum of the standard of fatty diethanolamide(Fig.-5). In the wavelength region of $3434-3451 \mathrm{~cm}^{-1}$, the vibration stretching of $\mathrm{OH}$ group is detected. Although in the amide structure there is an $\mathrm{N}-\mathrm{H}$ bond, however, no peaks are found at the wavenumber region of $3118-3191 \mathrm{~cm}^{-1}$, this is because the $\mathrm{N}-\mathrm{H}$ group in diethanolamide is a tertiary amine. In the region of $2941 \mathrm{~cm}^{-1}$, absorption of $(\mathrm{C}-\mathrm{H})$ alkanes is visible. The absorption band at $864 \mathrm{~cm}^{-1}$ is a typical wavenumber of the vibration of $\left(\mathrm{CH}_{2}\right) \mathrm{n}$ or long chain alkyl hydrocarbons. The successful of fatty diethanolamide synthesis is indicated by the appearance of 
RASĀYAN J. Chem.

Vol. 12 | No. 2 |765 - 772| April - June | 2019

absorption peak occurring at $1651-1655 \mathrm{~cm}^{-1}$, which is an area for $\mathrm{C}=\mathrm{O}$ stretching of carbonyl of the amide.

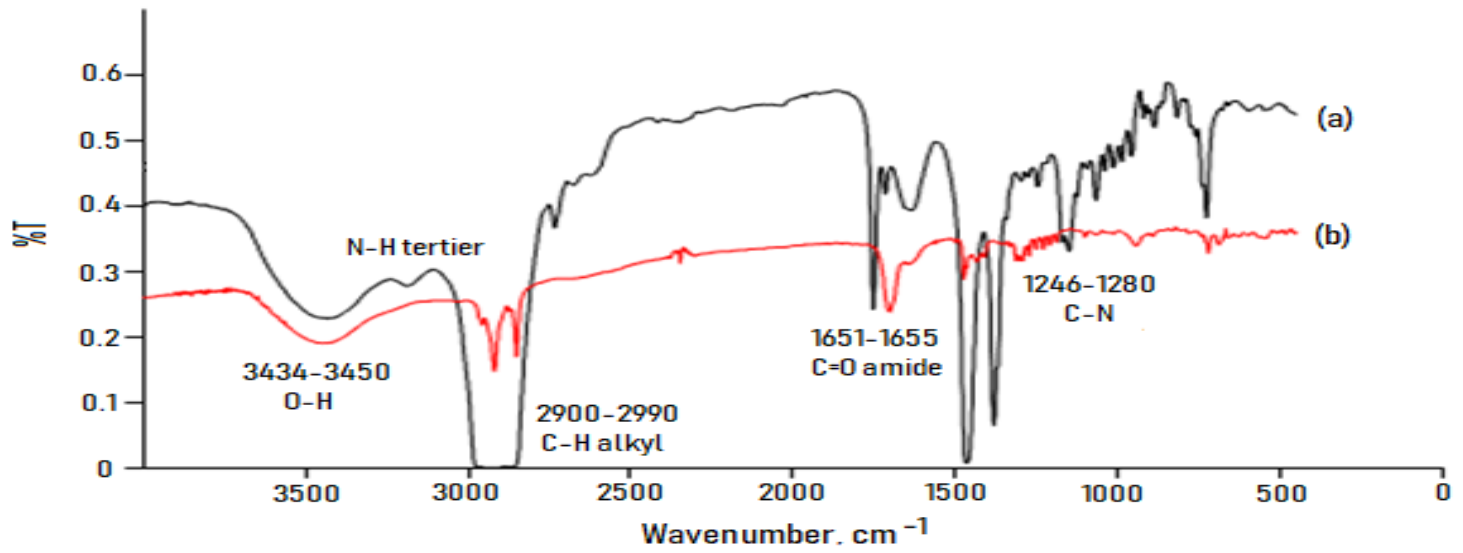

Fig.-5: FTIR Spectrum of Fatty Diethanolamide, (a) Product and (b) Standard

Meanwhile, the vibration of $\mathrm{C}=\mathrm{O}$ of the nyamplung kernel oil spectrum occurs at $1747 \mathrm{~cm}^{-1}$ (Fig.-6). This indicates that the ester group has been converted into the amide group in fatty diethanolamide ${ }^{27,28}$. The presence of amide groups is indicated by the presence of absorption bands at 1246-1280 cm-1 for stretching of C-N (Fig.-5).

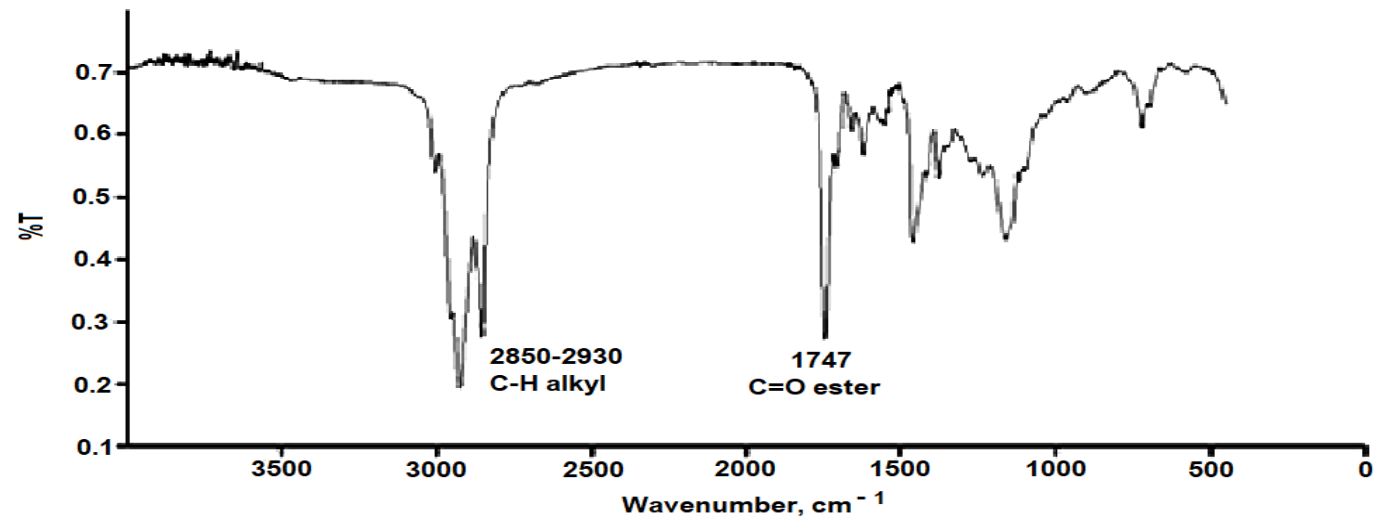

Fig.-6: The Spectrum of FTIR from Nyamplung Kernel Oil

Types of fatty diethanolamide formed can be determined by GC-MS analysis. A simple technique for identifying the type of sample in GC-MS is by comparing the retention time and fragmentation patterns of the product with those of the standard. Based on the GC-MS chromatogram (Fig.-7), the possible types of fatty diethanolamideof the product are palmitoyldiethanolamide, linoleyldiethanolamide and oleyldiethanolamide.

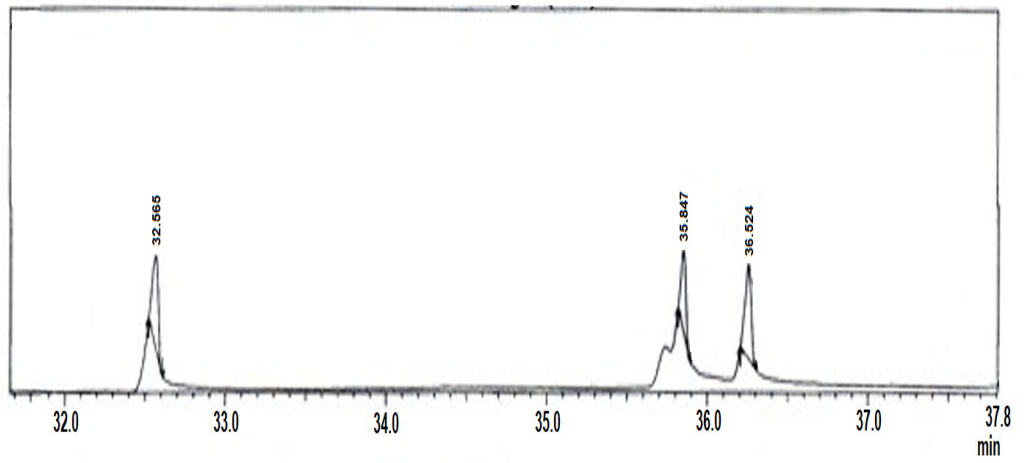

Fig.-7: Chromatogram of Fatty Diethanolamide; (1) Palmitoyldiethanolamide, (2) Linoleyldiethanolamide, (3) Oleyldiethanolamide 
This corresponds to the three highest compositions of fatty acids content in nyamplung kernel oil ${ }^{9,10}$. The fragmentation patterns for palmitoyldiethanolamide (peak 1, retention time, $\mathrm{RT}=32.565 \mathrm{~min}$ ) is 343

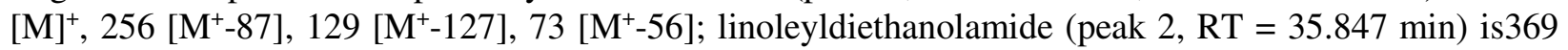
$[\mathrm{M}]^{+}, 284\left[\mathrm{M}^{+}-85\right], 129\left[\mathrm{M}^{+}-155\right], 73\left[\mathrm{M}^{+}-56\right]$; and oleyldiethanolamide (peak 3, RT = 36.524 min)is 367 $[\mathrm{M}]^{+}, 280\left[\mathrm{M}^{+}-87\right], 109\left[\mathrm{M}^{+}-17\right], 73\left[\mathrm{M}^{+}-36\right]$.

\section{CONCLUSION}

Fatty diethanolamide has been synthesized from non-edible vegetable oils, nyamplung kernel oil. Fatty diethanolamide synthesis from nyamplung oil using the optimum reaction conditions obtained a percentage of conversion of about 44\%. The types of fatty diethanolamide produced are palmitoylethanolamide, linoleic diethanolamide danoleyldiethanolamide.

\section{ACKNOWLEDGMENT}

The author thankful to the Director General of Directorate General of Research and Development Strengthening, The Ministry of Research Technology and Higher Education of the Republic of Indonesia, who has funded the research through the PDUPT 2018 research scheme.

\section{REFERENCES}

1. X. Wang, Y. Cen, Q. Jin, J. Huang and X. Wang, J. Oleo. Sci. 62(6), 427(2013), DOI: 10.5650/jos.62.427

2. C. Negin, S. Ali and Q. Xie, Petroleum, 3(2), 197(2017), DOI: 10.1016/j.petlm.2016.11.007

3. F.A. de Freitas, D. Keils, E.R. Lachter, C.E.B. Maia, M.I.P. da Silva, R.S.V. Nascimento, Fuel, 241, 1184(2019), DOI: 10.1016/j.fuel.2018.12.059

4. D.S. dos Santos, L.A. Piovesan, C.R. Montes D'Oca, C.R.L. Hack, T.G.M. Treptow, M.O. Rodrigues, D.B. Vendramini-Costa, A.L.T.G. Ruiz, J.E. Carvalho, and M.G. Montes D'Oca, Bioorganic \& Medicinal Chemistry, 23(2), 340(2015), DOI: 10.1016/j.bmc.2014.11.019

5. D. Kumar, H. Kuk and A. Ali, Journal of Industrial and Engineering Chemistry, 38, 43(2016), DOI: 10.1016/j.jiec.2016.04.004

6. F.N. Nisya, D. Prijono and A. Nurkania, Int. Conf. Biomass: Tech.App. Sustain. Dev. IOP Publishing, IOP Conf. Series: Earth Env. Sci.65, 1(2017), DOI: 10.1088/1755-1315/65/1/012005

7. D. Kumara and A. Ali, Fuel, 159, 845(2015), DOI: 10.1016/j.fuel.2015.07.046

8. H.C.Ong,H.H. Masjuki,T.M.I. Mahlia, A.S. Silitonga, W.T. Chong and K.Y. Leong, J.Energy Convers. Manag.81, 30(2014), DOI: 10.1016/j.enconman.2014.01.065

9. A. Atabani and A.César, Calophyllum inophyllum L. Renew. Sust. Energy Rev.3, 644(2014), DOI:10.1016/j.rser.2014.05.037

10. E.R. Gunawan, D. Suhendra, D. Asnawati, I.M. Sudarma and I. Zulpiani, In Proceedings of National Chemistry Conference, Surabaya Indonesia, B-147-158 (2014)

11. H.N. NjengaD.M. Mwaniki, J. Kenya Chem. Soc., 5(1), 1(2008).

12. R. Manurung, R.A.Sinaga and R.T Simatupang, Int. J. Innov. Res. Sci. Eng. Technol. 2(9), 4206(2013).

13. A.R. Lokhande, V.S.Patil andK.S.Wani,Int. J. Eng. Dev. Res., 4(4), 444(2016).

14. V.V. Bankar and R.P. Dhankar, Rasayan J. Chem, 11(3), 1294(2018), DOI: 10.31788/RJC.2018.1134012

15. E.R Gunawan, D. Suhendra, A.D.Nurita and D. Komalasari, Asian J. Chem., 29(10), 2107(2017), DOI: 10.14233 /ajchem.2017.20580

16. E.R. Gunawan, D. Suhendra, I. Hidayat and L. Kurniawati, J. Oleo Sci.67(8), 949(2018), DOI: 10.5650/jos.ess 18042

17. H.V. Patil, R.D. Kulkarni and S. Mishra, $\underline{w w w . f o s e t o n l i n e . o r g / A G A / 18-A G B}$, accessed on Januari 2019

18. A. Jahangiria, A.H. Møller, M. Danielsen, B. Madsen, B. Joernsgaard, S. Vaerbak, P. Adlercreutz, and T.K. Dalsgaard, Food Chemistry, 268, 203(2018), DOI: 10.1016/j.foodchem.2018.06.085 
RASĀYAN J. Chem.

Vol. 12 | No. 2 |765 - 772| April - June | 2019

19. J.Sun,B. Yu, P. Curran and S.Q.Liu, Food Chemistry, 134, 89(2012), DOI: 10.1016/j.foodchem.2012.02.070

20. M. Enayati, Y. Gong, J.M. Goddard, A. Abbaspourrad, Food Chemistry, 266, 508(2018), DOI: 10.1016/j.foodchem.2018.06.051

21. H. Kim, N. Choi, Y. Kim, H.R. Kim, J. Lee, and I.H. Kim, Renewable Energy, 130, 489(2019), DOI: $10.1016 /$ j.renene.2018.06.092

22. P.W. Kuchel, G.Pages and C.Nauman, FEBS Letter, 587(17), 2790(2013), DOI: 10.1016/j.febslet.2013.05.025

23. D. Suhendra, E.R. Gunawan, A.D. Nurita, D. Komalasari and T. Ardianto, 66 (3), 209(2017), DOI: 10.5650/jos.ess 16167

24. M. Cruz, S.C. Pinho, R. Mota, M.F. Almeida, and J.M. Dias, Renewable Energy, 124, 165(2018), DOI: 10.1016/j.renene.2017.06.053

25. V. Worthington,Introducing to Enzymes. Worthington Biochemical Co. New Jersey.(2010)

26. C. S. Lee, T. L. Ooi, C. H. Chuah and S. Ahmad, J Am. Oil. Chem. Soc.84, 945(2007), DOI: 10.1007/s11746-007-1123-8

27. A. Adewuyi, R. Oderinde, B.V.S.K. Rao and R.B.N. Prasad, J. Surfact. Deterg.15, 89(2012), DOI: 10.1007/s11743-011-1285-0

28. F. Sari, B.H. Susanto, S. Bismo, IOP Conf. Ser.: Earth Environ. Sci., 105 (2018), DOI: $10.1088 / 1755-1315 / 105 / 1 / 012035$

[RJC-5147/2018] 